\title{
Peace Unwanted? - The Frozen Conflict of Nagorno-Karabakh Revisited
}

\author{
Pia Ferner
}

International Development, Wageningen University

\begin{abstract}
More than twenty years after the ceasefire agreement has been signed between Armenia and Azerbaijan, little has been reached in resolving the dispute over Nagorno-Karabakh. This paper aims to provide insight into political dimensions of the conflict combining a geopolitical perspective with a perspective of local dynamics on the ground. Analyzing contributing factors to the lack of progress in the durable settlement of the conflict over Nagorno-Karabakh provides an outlook on possibilities for a peaceful settlement of the dispute, which is of high relevance from a humanitarian perspective. The current positions of international actors contributing to the stalemate, as well as a lack of influential involvement of the civil society in the region provide little reason to believe significant change for a peaceful settlement of the conflict will be made in the near future. Increased transparency and improved communication are needed to provide opportunities for a peaceful change.This paper is primarily based on desk research, with additional insights gained from a research stay, and was issued as a contribution to Indonesian Humanitarian Action Forum. It is seen as an opportunity to shed light on an often forgotten conflict which poses strong humanitarian concerns due to a large number of IDPs (Internally Displaced Person) and continued landmine contamination hindering development.
\end{abstract}

Keywords: Frozen conflict, stalemate, conflict resolution, South Caucasus

\begin{abstract}
Abstrak
Lebih dari dua puluh tahun pasca persetujuan gencatan senjata ditandatangani oleh pihak Armenia dan Azerbaijan, hanya sedikit yang telah dicapai untuk menyelesaikan sengketa terkait Nagorno-Karabakh. Tulisan ini memiliki tujuan untuk memberikan wawasan tentang dimensi politik dari konflik tersebut dengan mengkombinasikan perspektif geopolitik dengan perspektif dinamika lokal. Dengan menganalisis faktor-faktor yang memberikan kontribusi pada kurangnya progres dalam penyelesaian konflik NagornoKarabakh dapat diperoleh sebuah pandangan tentang kemungkinan penyelesaian sengketa secara damai, yang mana merupakan hal yang memiliki relevansi tinggi dari perspektif humaniter. Posisi yang saat ini diambil oleh aktor-aktor internasional memiliki kontribusi terhadap kebuntuan konflik saat ini, termasuk pula kurangnya keterlibatan aktif dari masyarakat sipil di kawasan memberikan sedikit alasan untuk percaya bahwa perubahan signifikan ke arah penyelesaian konflik secara damai akan dilakukan dalam waktu dekat. Peningkatan transparansi dan komunikasi yang lebih baik dibutuhkan untuk memberikan kesempatan bagi perubahan secara damai untuk dapat terwujud. Tulisan ini terutama didasarkan pada studi literatur, dengan tambahan pemahaman yang didapat dari penelitian di lembaga riset, dan telah dikumpulkan sebagai kontribusi terhadap IHAF. Keberadaan tulisan ini dapat dilihat sebagai momentum yang baik untuk menyoroti konflik yang kadang terlupa namun membutuhkan perhatian humaniter yang besar karena banyaknya jumlah pengungsi internal dan masih berlangsungnya kontaminasi ranjau darat yang menghambat pembangunan.
\end{abstract}

Kata kunci: konflik beku, jalan buntu, resolusi konflik, Kaukasius Selatan 


\section{Introduction}

"The Armenian-Azerbaijani conflict may not have been the worst of modern wars, but it has produced one of the worst peaces."(de Waal, 2003: 270)

Official end of the Nagorno-Karabakh war was marked in 1994, when a ceasefire agreement was signed by representatives of Armenia, Azerbaijan and Nagorno-Karabakh. More than twenty years later 600.000 people are still living as Internally Displaced Persons (IDPs) in Azerbaijan, having fled from the region now forming the unrecognized Nagorno-Karabakh Republic (NKR), as a result of the territorial conflict. Internationally the region is being recognized as de jure part of the Republic of Azerbaijan, respecting its right to territorial sovereignty. NagornoKarabakh is, however, de facto independent. This leaves the issue of IDPs, which is among the highest IDP numbers per capita on a global scale, largely unresolved (IDMC, 2014; Moser, 2012; Özkan, 2008).

Peace negotiations did not lead to an agreement, leaving people in the area in a state of "no war, no peace". Geopolitical interests seem to contribute to a stalemate and de facto non-interference. The "freezing" of the conflict leaves the two main conflicting parties without necessary will for compromise. Changing economic power, which is reflected in growing military expenditures of Azerbaijan, raises concern that a solution of the conflict will be of violent nature. Renewed shootings and casualties on the frontline, between NKR and Azerbaijan proper, in August 2014, as well as repeated reports of landmine incidents, alarmingly show the fragility of the ceasefire in place (de Waal, 2003, 2010). These humanitarian concerns reveal the need to bring this protracted conflict back on the international agenda in order to actively seek a peaceful settlement for the conflict. The key question is, which factors have contributed to the lack of progress in a durable settlement of the conflict over Nagorno-Karabakh?

International incentives seem low for the conflict being resolved, considering that current and past official political attempts remain unsuccessful. A review of recent literature on the case of Nagorno-Karabakh in the broader domain of peace and conflict, with particular regard to frozen conflict settings, is intended to shed light on the current stakes of parties involved in the peace process in order to provide indications for underlying reasons of the "frozen" character of the conflict. The analysis is primarily based on desk research. However, insights gained through a 2-months field visit, investigating local perceptions on the presence and impact of landmines in NKR contributed to a broader understanding of the regional conflict. By combining analysis of geopolitical as well as local developments affecting the conflict dynamics, this paper tries to contribute to current discussions on a peaceful resolution of this and other frozen conflicts.

Furthermore, an analysis of reasons for a continued existence of unrecognized de facto states should be a basis for designing adequate responses to the current stalemate in order to foster positive development in the peace process. An exploration of relevant factors that have hindered a peaceful resolution of the protracted conflict and a thorough case description can serve as a basis for researchers to apply theoretical concepts and design comparative research. Focusing on the roles of various stakeholders in the peace process is intended to shed light on possible reasons for a preservation of the status quo. In part, this can be linked to geopolitical factors posing obstacles to international peace efforts, hindering political actors from going beyond mere lip service. It is this intertwined interest from local as well as global powers, which are shaping the dynamics of the conflict on the ground that is of particular interest. After a brief examination of the context of the conflict and undertaken peace efforts, various positions of geopolitical actors and local stakeholders involved in peace and conflict dynamics in the South Caucasus are taken as a basis for analysis. These attitudes form an integral part for the discussion of the current deadlock in the peace process and a critical analysis, in whose interest it is to peacefully resolve the protracted conflict. 
The Conflict over Nagorno-Karabakh and NKR at Present in a Nutshell

The current struggle over the status of the territory of Karabakh revolves around competing claims of the opposing parties. While Azerbaijan claims territorial integrity, as is recognized under international law, Nagorno-Karabakh claims its right to selfdetermination or de facto independence and secession from Azerbaijan proper (Baguirov, 2012; Moser, 2012; Uzer, 2012; de Waal, 2003).

During the period of the Soviet Union, Karabakh had the status of an "Autonomous Oblast" within the Soviet state of Azerbaijan with the greater share of the population being of Armenian descent. There had been aspirations for a reunification of Karabakh Armenians with its ethnic majority, but it was in the wake of the dissolution of the Soviet Union that greater political mobilization was possible. First violent outbreaks occurred in 1988. As dissent progressed, NagornoKarabakh Republic was formed in 1991, striving for secession from the host country, claiming the right to self-determination. The same year a process of political reorientation was initiated, with the forming of the Republics of Armenia and Azerbaijan, motivating the predominantly Armenian population of Karabakh to claim reunification with Armenia proper which gradually transformed into a fight for independence (Cheterian, 2012; Prokola, 2015).

The complexities of the geographic and political reorientation of post-soviet states impacted strongly on the dynamics of the conflict in the region. Huseynov (2010) strikingly identifies three dimensions of the Karabakh conflict, quoting an (1) inter-state level between Armenia and Azerbaijan as conflicting parties, an (2) intra-state level focusing on the dispute between Azerbaijan and Karabakh-Armenians as well as an (3) inter-communal dimension concerning differing interests among the Karabakh population between people of Armenian and Azeri origin. The war officially ended with the signing of the ceasefire agreement in 1994 and resulted in the occupation, not only of traditional Nagorno-Karabakh, but also surrounding Azerbaijani districts by Armenian forces, which make up the territory of NKR today. This created a buffer zone between the opposing parties and serves as important leverage for Armenia in current peace negotiation processes (Özkan, 2008). The population of the unrecognized NagornoKarabakh Republic today counts approximately for 145.000 inhabitants comprising almost exclusively of people of Armenian decent (NKR, 2012).

\section{Peace Efforts since the Signing of the Ceasefire Agreement}

Nagorno-Karabakh represents the only conflict zone in the South Caucasus that did not receive any form of support through a deployment of peacekeeping forces. The current ceasefire agreement, in place since 1994, remains self-sustained (Gahramanova, 2007). However, a dispute, impossible to be resolved by the conflicting parties, requires active involvement from external parties. In many cases the UN can act as intervening body in humanitarian crises and conflict. However, in the case of Karabakh, the UN holds only a minor role, following a tracksharing approach, giving way to regional organizations to take up mediating roles in the peace process. The UN Security Council does call for a 'withdrawal of all occupying forces', but does not actively get engaged in peace efforts, giving responsibility to the Comission on Security and Cooperation in Europe (CSCE), which later became the Organization for Security and Cooperation in Europe (OSCE) (Gahramanova, 2007).

\section{OSCE as Peace Broker}

The OSCE Minsk Group has to be seen as the most prominent actor in the attempt of solving the Karabakh conflict permanently. The group, which came into being in 1992, consists of 11 permanent member countries ${ }^{1}$ led by the co-chair of Russia, the USA and France, as the main actors in the peace negotiations (Gamaghelyan, 2010; Moser,

${ }^{1}$ The Minsk Group comprises of the following member statres: Belarus, Germany, Italy, Sweden, Finland,

Turkey, Armenia, Azerbaijan, as well as three co-chairs. 
2012). The Minsk Group elaborated on several proposals for a peaceful settlement of the conflict in the South Caucasus with the Madrid Principles being of main interest to the parties involved, as negotiations are considered so far (NKRUSA, 2002).

The Madrid Principles, or Madrid Proposals, refer to a proposed solution from November 2007, which representatives of the United States of America, France and Russia presented to the foreign ministers of Azerbaijan and Armenia, identified as the "principal parties" ${ }_{2}$ to the conflict over Nagorno-Karabakh, in order to finally settle the dispute. According to these principles, both conflicting parties need to show willingness for compromises as is expressed in six defined steps to be fulfilled for a peaceful settlement (Moser, 2012; Potier, 2012). The two conflicting parties refer in this case to Armenia and Azerbaijan and their respective political representatives. However, the process does not support engagement of representatives of Karabakh. The current and former population of Karabakh is left out of the direct negotiation process, although representing the core concern of the peace talks (de Waal, 2010). The six principles comprise of:

1. Territories surrounding NagornoKarabakh need to be returned to Azerbaijan

2. Provision of guaranteed security and selfgovernance through an interim status for Nagorno-Karabakh

3. Establishment of a linkage corridor between the Republic of Armenia and Nagorno-Karabakh

4. Determination of the final legal status of Nagorno-Karabakh

5. Granting the right to all IDPs and refugees in/from the region to return to their former places of residence

6. Establishing international security measures such as a peacekeeping operation

\footnotetext{
${ }^{2}$ It is interesting to note that the ethnic communities of the contested region are not recognized as main parties to the conflict, but are labeled as "interested parties". (For further information see Baguirov, 2010)
}

Even though Armenia and Azerbaijan agreed on the importance of addressing these steps for a resolution of the conflict, the countries lack the willingness for compromise. Moreover, the three co-chairs of the Minsk Group appear to lack a united and concerted effort for a peaceful settlement of the conflict (Moser, 2012). While Russia and the USA represent influential powers in the region, the role of France seems to be of lower significance, joining the Minsk group primarily because it is host to a significant share of Diaspora Armenians, trying to cater for peoples' claims in their "homelands". However, France does not find much mentioning in past and current literature concerning the Nagorno-Karabakh peace process.

The collective peace approach of the Minsk group is difficult to be separated from particular national interests of the countries involved in the peace negotiations. Driving forces within the Minsk group can be linked to domestic interests. In part, engaged parties have to be seen as biased entities and it is difficult to determine in whose interest representatives act.

According to Gahramanova (2007), conflicts are often settled according to selfinterests of the mediators rather than truly considering the conflicting parties directly affected by the conflict. A biased mediator can contribute to a halt in peace negotiations while successfully retaining post-war conditions. As will be shown in an analysis of stakeholders, some countries, also represented in the Minsk Group, ultimately serve their own governments interest. This seems to be one of the weakest points of the peace brokers in the process.

\section{The Stakes of the Principal Conflicting Parties}

Analyzing the meaning and role of the territory of Karabakh for Armenia and Azerbaijan, it becomes clear that the region is only of little strategic significance. However, the dispute over the region gained momentum in the wake of nation-building processes after the dissolution of the Soviet Union. In this context Karabakh then, serves as a tool for 
demarcating boundaries in the nationbuilding process of these young post-Soviet nation-states, forming an integral symbolic part of national identities for both ethnic communities (Özkan, 2008; Uzer, 2012). For both nations, the region is laden with historical meaning, impacting on the construct of national identity, feeding into the proliferation of the conflict (de Waal, 2003). In addition to the strong symbolic value of territory, both parties further carry narratives of victimhood, portraying their own acts as necessary means of self-defense, perceiving the 'other' as the aggressor (de Waal, 2003).

Armenia's role and interests in the conflict seem to be twofold. On the one hand, the country acts in line with the international community by refusing to recognize the independent status of NKR. Furthermore, the country negates being an active part in the conflict, instead, identifying Karabakh as conflicting party with Azerbaijan. On the other hand, Armenia is not acknowledging that the current presence of Karabakh-Armenians within NKR is a violation of the territorial integrity of Azerbaijan by the occupying forces (Kurkchiyan, 2005). Links between Armenia and Nagorno-Karabakh get further complicated when examining the countries' political landscapes. Important political figures of Armenia served in political positions in Nagorno-Karabakh with Robert Kocharian serving as one example. He used to serve as President of the NKR from 1994-1996, continued his career as Prime Minister in 1997 and a year later as President of the Republic of Armenia from 1998-2008 (Özkan, 2008; President, n.d.). Furthermore, some important domestic affairs such as military functions are organized jointly, with the armies of Armenia and Nagorno-Karabakh working as one unit and decisions being made jointly (de Waal, 2010). In addition, the two states are economically intertwined, with Armenia proper covering about half of Nagorno-Karabakh's total budget (Huseynov, 2010).

Azerbaijan, on the contrary, needs to cope with the territorial losses of approximately $13-14 \%$ of its total territory (de Waal, 2003). Similar to Armenia, the historical and national meaning of Karabakh is continuously reproduced in national rhetoric, rendering the regaining of its territory high on the state's political agenda. The lack of finding a durable solution to the IDP question often is linked to the lack of a political solution of the conflict itself. The issues of IDPs and refugees serve as leverage in the peace process, resembling the need to provide ways for a safe return of Azeris from Karabakh. If no peace resolution can be agreed upon, the country shows readiness to use armed forces to restore its territorial integrity. Economic development in Azerbaijan, mainly due to its energy reserves, enables the state to re-arm its military forces. Therefore, Azerbaijan leadership sees time "playing for its side" (Cheterian, 2012: 707708; Gahramanova, 2012).

Comparing the current stance of the two main conflicting parties, it seems that Armenia bases its negotiations on its military success of the past, coming out as winner of the war, while Azerbaijan relies on its growing military power (Gahramanova, 2007).

\section{The Nagorno-Karabakh Peace Process from the Geographical Neighbors' Perspective $3^{3}$}

The geopolitical situation in the South Caucasus is in large part influenced by the Karabakh conflict, dividing geographical neighbors. In this complex political environment, it is of interest to look at relevant parties shaping the conflict, unraveling underlying motives for a settlement (or upholding) of the dispute in order to evaluate possibilities for successful peace efforts. Instead of a shared regional identity and cooperation, the countries of the South Caucasus seek national security through bilateral agreements with external actors. This leads to a certain extent to a "great powers game", receiving greater international relevance in part due to Azerbaijan's oil reserves and the construction of relevant

3 Georgia does not find distinct mentioning, since it seldom appears in detail in any geopolitical analysis on Nagorno-Karabakh and is often dealt with separately in relation to conflicts over the breakaway regions of Abkhazia and South-Ossetia. 
transport routes of the Caspian Sea oil (Gahramanova, 2007; de Waal, 2003). The conflict situation of Karabakh has wider implications for the region, particularly in terms of security and possible disruptions of economic cooperation.

\section{Continued Presence of Russia}

Historically, Russia, or the former Soviet Union, established a relatively strong presence in the region during the past century up until today. In addition, it was one of the first countries attempting to render peace negotiations possible, acting as a mediating force between opposing parties of the conflict. Russia was shaping the course of the strife greatly by ultimately succeeding in the agreement on the armistice of 1994, which often is thought to be the result of efforts taken by the Minsk Group (de Waal, 2010; Harutunian, 2010). The Russian involvement in the peace process is particularly marked by its 2008 attempt to act as a peace broker, resulting in Armenia, Azerbaijan, and Russia signing the Moscow Declaration, based on the Madrid principles4 (Kasim, 2012).

Russia acquires a double role in ongoing negotiations. Firstly, Russian representatives exert influence through the co-chairmanship of the Minsk Group. Secondly, Russia still represents a dominant regional power, following its own political agenda (Harutunian, 2010). Russian influence in the region is in part linked to Armenian dependency on Russia economically, politically, as well as in terms of military support (Kasim, 2012). Russia provides safety guarantees for Armenia, assuring direct Russian involvement in the conflict in case of a military strike of Azerbaijan against its neighbor (Moser, 2012). Furthermore, Armenia is a member of the Collective Security Treaty Organization (CSTO) 5 , which is led by Russia and can be seen as a

4 According to the agreement, Armenia and Azerbaijan, as the two direct opposing countries without taking into account NKR, will attempt to solve the conflict adhering to norms and principles of international law.

5 CSTO represents an intergovernmental military alliance similar to NATO (North Atlantic Treaty Organization); for more information see i.e.

http://www.odkb.gov.ru/start/index aengl.html (official representation of CSTO) counterpart to the NATO (Huseynov, 2010). Russia's relations with Azerbaijan are often reported to be disrupted. However, it has to be noted that there is some form of exchange at least in terms of military trade. $^{6}$ Russia obtains diplomatic relations with Azerbaijan regarding some economic affairs.

Uzer (2012) identifies Russia as one of the most critical actors in the current "no peace-no war" situation in the South Caucasus. It contributed to the Armenian military success during the Karabakh war in the 1990 supporting troops, while at present acting as a mediator between the conflicting parties, being among the driving forces of the current peace negotiations. Despite its mediating role, Russia and other actors in the region are perceived as favoring the status quo of the conflict being in a "frozen" state, creating certain dependencies between states. By preserving the status quo, Russia can continue its political and economic relations with both parties. A change in conflict dynamics might jeopardize the currently beneficial cooperation. Russia's political agenda can be summarized as an attempt to remain an influential political power in the region (Gahramanova, 2007).

\section{Turkey's "Brotherly" Ties to Azerbaijan}

Part of the complex geopolitical situation in the Caucasus is the fact that two of the four international borders of Armenia are closed, with Turkey in the west and Azerbaijan in the east. The trigger for the closure of the Turkish-Armenian border was the continuation of the occupation of Azerbaijani territory by Armenian forces from 1993 onwards. Further lobbying efforts of Azerbaijan in Turkey were aimed at ensuring a continued closure of borders until a final resolution of the conflict in NagornoKarabakh. Turkey's support for Azerbaijan is primarily based on ethnic and linguistic ties. The two states further offer each other support in economic and military terms (Abushov, 2009; German, 2012; de Waal, 2003; Kasim, 2012).

\footnotetext{
${ }^{6}$ In mid-2013, e.g. a $\$ 4$ billion arms trade between Russia
} and Azerbaijan was reported. See i.a. Agayev (2013) 
Armenian and Turkish relations are complicated by a number of unresolved issues, with the question of the recognition of the Armenian genocide in Turkey dating back to 1915 being one of the prominent issues. Despite diplomatic approaches being made between Armenia and Turkey in the past, recent failures give evidence that the two countries have differing interests in relation to the settlement of the Nagorno-Karabakh conflict and its impact on diplomatic as well as economic relations. Similar to Russia, Gahramanova (2007) identifies an interest of Turkey in upholding the current situation of "no war, no peace" in the South Caucasus. While officially showing strong support for Azerbaijan, Cheterian (2012) points out, that secret meetings between Armenian and Turkish diplomats have been taking place in order to ease tensions between the two respective countries as part of Turkey's new approach in its foreign policy towards the east since 2007. In spite of more recent advances of the two geographic neighbors, approaches failed again due to remaining conflicts of interest. While Turkey's attempts were described as only short-term efforts, trying to deflect from other ongoing political issues, Armenia's approach in normalizing relations was completely detached from the conflict with Azerbaijan (Cheterian, 2012; Ambrosio, 2011).

\section{Iran's Secondary Role In the Conflict}

Due to Armenia's tense relations to half of its' neighboring countries, Iran forms an integral part in Armenia's foreign relations and cooperation. Iran, together with Georgia, provides essential trading opportunities for Armenia and supported its neighbor in the north economically during the war. A balance of power between Azerbaijan and Armenia is in the interest of Iran (Gahramanova, 2007).

Overall Iran is taking up a minor role in the current conflict dynamics, seeking a balance of powers with commercial ties to Armenia and cultural similarities with Azerbaijan. Russia's approach of counteracting the US presence in the region seems beneficial to Iran (Abushov, 2009).

\section{Omnipresence of the USA - Balance of Power In Place?}

The US position in the peace negotiations appears to be twofold. On the one hand, importance is given to Azerbaijan's energy resources that require the US to respect the territorial integrity of the country in the South Caucasus due to its own political and economic interests. On the other hand, domestic concerns, linked to the Armenian Diaspora, complicate the US position in the process of conflict resolution and hinder the country to act as reliable broker with different interests driving its efforts and actions in the region (Kasim, 2012). However, despite these contrasting motives, the US is widely perceived as a neutral part in the negotiation process with the oil lobby as well as the Armenian lobby maintaining an equilibrium in interests and motivations (Gamaghelyan, 2010).

American involvement in a settlement of the conflict dates back as far as 1989 when the US Senate approved a resolution stressing the country's support for the fundamental rights of the people of Nagorno-Karabakh, campaigning for a non-violent settlement of the regional dispute (NKRUSA, n.d.). To elaborate further on the role of the US, attention needs to be given to the Freedom Support Act of 1992, also known as "Freedom for Russia and Emerging Eurasian Democracies and Open Markets Support Act"7 which enables the provision of US foreign assistance to the newly established states. Through the policy framework of the Freedom Act with special reference to section 907, the Armenian lobby in the US successfully prevented US American humanitarian assistance being delivered to Azerbaijan, portraying Azerbaijan as the perpetrator of violent conflict in Nagorno-Karabakh. This further complicated US-Azerbaijan relations. For the US, the Armenian Diaspora resembles the biggest hindrance for cooperation with Azerbaijan. One turning point in US policies regarding issues in the Caucasus was set by 9/11 terrorist attacks in 2001. Higher attention to security issues and important

7 For detailed information see Tarnoff (2004). 
coalition troop support through Azerbaijani supply routes to Afghanistan gave way to the revocation of US aid sanctions towards Azerbaijan. American domestic affairs did impact on an increased American presence in the Caucasus region with the secondary effect of lowering Russian dominance in the region (Kasim, 2012; NKRUSA, n.d.). Aside from an "internal balance" of interests, the US involvement in the South Caucasus also acts as a balance of Russia's continued presence and exertion of power in the region (Gahramanova, 2007).

Several authors identify the US potential to positively influence a final settlement of the protracted conflict. However, there seems to be a lack of incentives for greater involvement of the US, not showing a particular interest in the region of Nagorno-Karabakh or gaining sufficient benefits from successfully brokering peace between the conflicting parties (i.a. Kasim, 2012; U. Uzer, 2012). Furthermore, Ambrosio (2011) indicates that other foreign policy issues of the US rank much higher in priority than Nagorno-Karabakh with a considerably low level of tension and violence. Whilst the Obama administration officially identifies Nagorno-Karabakh as one of their policy priorities, it did not receive much attention in recent years (Ambrosio, 2011).

\section{Civil Society as A Last Resort?}

In recent years growing attention and recognition has been given to the potential and transformative power of civil society (CS). Renowned institutions such as the World Bank (2013) describe today's active role of civil society organizations as crucial in the social and developmental sector, particularly in circumstances of weak state governance as is often the case in post-conflict environments. When a lack of state interest in a peaceful resolution of the conflict becomes apparent, the question on the power of people to achieve durable change can be raised.

These perceptions paired with the absent success of efforts by political elites' to advance peace negotiations, move an examination of the role of civil society in the effort of peacefully resolving the several decades of long conflict over the region, to the fore.

According to Victor Chirila, executive director of the Foreign Policy Association of the Republic of Moldova, "future settlement needs a complex approach that would involve not only political negotiation but also civil society dialogues, confidence and partnership building and reconciliation,"(Chirila, 2013).

In 2009 the "Civil Society Forum"8 was launched, which is intended to take the lead in promoting non-political dialogues and alternative routes for a settlement of the conflict in Nagorno-Karabakh through promoting eastern partnerships. This development can be seen as a promising move in the right direction, but recent developments in the region show that much work needs to be done, especially when it comes to changing peoples' minds and perception on a more than 20 year lasting conflict (Chirila, 2013).

However, opposite tendencies on local peoples motivation for a peaceful settlement of the conflict can also be observed. When recent clashes along the frontline occurred in August 2014, the way social media was used by local residents of Nagorno-Karabakh suggests only limited effectiveness of CS efforts. The recent military clashes seemed to stir up anger rather than condemning outbreaks of violence. This was for instance reflected for in pictures of the frontline being posted depicting men in military outfits, ready to fight in solidarity with their troops, raising their guns and other posts blaming the enemy for being responsible for escalations. ${ }^{9}$

Furthermore, some local $\mathrm{CSOs}^{10}$ are taking on a strongly biased view, repeating their governments' claims for a resolution of the conflict, following the lead for "national justice" instead of a settlement based on mutual compromise and constructive peace negotiations.

\footnotetext{
8 The Forum brings together National Platforms of Armenia, Azerbaijan, Belarus, Georgia, Moldova, and Ukraine. More information to be found on: http://eapcsf.eu/

${ }^{9}$ It has to be stated that these observations can only be seen as "snapshots" based on personal connections to former respondents and friends residing in NKR. No general claims can be made.

1o See e.g. "All for Karabakh - Virtual Campaign” (Az.)
} 
This attitude of the general public has to be linked with the political framing of the conflict. As Gahramanova (2007) points out, possible causes of the conflict are linked to a particular political environment in the Nagorno-Karabakh region in which identity based on ethno-territoriality provides a basis for mass mobilization. The author further suggests the urgent need of transforming this "ethnic hatred discourse" into a "peace discourse".

On the one hand a main concern lies in the lack of participation in ongoing peace and reconciliation efforts of the peoples of Armenia, Azerbaijan and Karabakh respectively, due to a lack of information on, and transparency of the peace process. The attempts of resolving the conflict are quite elitist, handled on a political level by few diplomats and politicians. On the other hand, there seems to be no social demand for peace. No considerable efforts are made by the general public to pressure politicians for a sustainable solution of the long-lasting conflict (Cheterian, 2012).

\section{The Current Deadlock In the Peace Process}

Ever since the official cessation of hostilities, only little progress has been made towards a durable solution to secure peace in the region. Hopmann and Zartman describe the current situation in Nagorno-Karabakh as "an $\mathrm{S}_{5}$ Situation - a soft, stable, self-serving stalemate" (Hopmann, 2010: 2). Moser criticizes the efforts of the peace process, calling attention to the lack of well-respected mediators without superior motives, as has been shown in party by the analysis of Russia and the US. Actors seem to be driven by economic or political self-interest in the region rather than acting as neutral negotiators (Moser, 2012). Similarly, Harutunian (2010) argues that peace brokers do not appear to be entirely impartial. Nevertheless, they play an influential role in preventing further violence, keeping the conflict in a "frozen" state. Babbit (2006) states that despite their regional and global influence and power, mediators did not exert sufficient pressure and leverage for conflicting parties to come to an agreement. In addition, differing interests among the mediating parties reduce their impact on resolving the ongoing conflict. Bilateral agreements on energy, security and trade between mediators and conflicting countries further contribute to the intractability of the conflict with the lack of impartial peace brokers (de Waal, 2010).

An explanation for the prolonged state of conflict offered by Özkan (2008), states that parties involved in the negotiation processes gain from the current deadlock, which ultimately leads to a delayed or stalemated peace process. On an international scale, the security threat is considered to be rather low, putting issues of the South Caucasus off the priority agendas of the international community. The ones bearing the costs of the frozen conflict situation are the societies of the respective countries suffering from restricted movement and blockades. (Özkan, 2008)

Several scholars (i.a. Babbitt, 2006; Huseynov, 2010; Milanova, 2003; Özkan, 2008) criticize the current peace process for being restricted to Track $1^{11}$ efforts rather than involving the greater public and civil society. De Waal even refers to the NagornoKarabakh peace negotiations as "some of the most secretive and least inclusive peace talks in the world" (de Waal, 2010: 168). A lack of participation and marginalization of civil society in efforts of conflict resolution is being observed in a number of states formerly being part of the Soviet Union. In these ex-Soviet countries mostly a gap between state-rule and society exists that yet needs to be overcome, especially in areas where conflicts need to be redressed (Ghaplanyan, 2010).

Apart from the political complexity of the peace negotiations, another result of the unresolved conflict is the amount of IDPs and refugees created by the conflict, which remains an issue up until today. The social costs of the current stalemate are high for the population of Nagorno-Karabakh regardless of peoples' ethnic origins, totaling in more than a million refugees and IDPs (Özkan, 2008). Roughly half a million of Azeris remain

\footnotetext{
${ }_{11}$ Track 1 diplomacy usually refers to government
} interactions, only involving state-actors. 
in camps waiting for a permanent solution of their situation. A total number of 750.000 displaced Azeris and around 350.000 Armenians were forced to leave their homes throughout the course of war, expelling people from the countries of Azerbaijan and Armenia. Even after a successful peace agreement would be signed, estimates state that it could take 5-10 years until returnees, especially in border regions, could live in a habitable environment again (de Waal, 2003; Gamaghelyan, 2010).

Another development Geybullayeva (2012) observes since the 1994 ceasefire agreement is the negative rhetoric and nationalist propaganda used and spread especially by domestic media in Armenia as well as Azerbaijan. The region of Karabakh is laden with different meanings and interpretations of e.g. culture, values and historic roots for both countries and ethnic groups (Geybullayeva, 2012). As Özkan (2008) puts it, "the most significant barrier for peace in Nagorno-Karabakh is the constructed image of 'the other' as a source of threat in the eyes of the people" (594). Through means of mass media and its utilization by political elites the opposing parties in the conflict are framed in particular ways, hindering lasting peace (Özkan, 2008).

\section{Conclusion}

Absence of international media attention contributes to Nagorno-Karabakh earning the label of a forgotten conflict. A lack of international pressure leaves the two main parties of the conflict, Armenia and Azerbaijan, without any incentives to open up for real compromise between the conflicting parties. As the winner of the war, Armenia shows little interest in changing the status quo. There is certain leverage exerted on Armenia through the closed borders with its neighbors in the east and west. However, these restrictions do not seem effective in pressuring Armenia to return occupied territory. At the same time, Azerbaijan sees time as an important indicator for their eventual success on solving the Karabakh conflict in their interest. Oil revenues contribute to growing military power, preparing for a possible future war.

Time has to be seen as a critical factor when looking at the "frozen conflict" over Nagorno-Karabakh. The current short-term approaches of external actors in keeping Armenia and Azerbaijan from falling back to war are linked to a high level of uncertainty and insecurity in the region. With a lack of commitment to peace negotiations Karabakh remains a ticking time bomb. This becomes particularly evident when looking at Azerbaijan's military expenditures.

Most negotiations, agreements and efforts undertaken so far in the peace process can predominantly be interpreted as lip service, lacking serious commitment and visible results in creating positive change for the conflict region. This seems particularly evident when looking at particular national interests of various parties involved in the peace negotiations and in cooperation with the main conflicting parties. The current deadlock seems to be profitable for all geopolitical powers at play, keeping a balance between the forces while profiteering through bilateral cooperation. Exerting pressure on one or both sides of the conflict might jeopardize diplomatic relations of the peace brokers with the conflicting parties, which no one seems to be willing to risk. No external power shows interest in a violent settlement of the conflict, but neither do they intend to change the status quo, seeking for viable peaceful long-term solutions.

The potential of civil society in advancing peace talks also has to be reviewed critically. So far no strong will and motivation to get actively involved in peace resolution efforts has been expressed by local people directly affected by the conflict. There is little indication for people's dissatisfaction about the course of the peace talks and their respective governments. Expression of political criticism could aid in building up political pressure for a final peaceful settlement of the conflict. More transparency and increased communication between governmental representatives and the public, as well as across national borders is needed to move the peace negotiations forward. In 
addition, international efforts should be better concerted, with the OSCE Minsk Group acting as unified body, reducing the chance of member countries to act out of self-interest.

The current positions of stakeholders in the peace process raise the cynical seeming view that peace seems to be in no one's interest. However, what cannot be forgotten is the remaining unresolved issue of IDPs and a pressing uncertainty in the region that seemingly can change any time for the worse, causing great human suffering. Even though the dispute over Nagorno-Karabakh is of low intensity and therefore receives little international attention, serious peace efforts need to be made in order to ease people's insecurity and to create an environment conducive for social and economic development in the region and of its people.

\section{Bibliography}

\section{Books}

Herzig, E., \& Kurkchiyan, M. (Eds.). (2005). The Armenians: past and present in the making of national identity. Abingdon, Oxon, Oxford, New York: RoutledgeCurzon.

Kurkchiyan, M. (2005). The Karabagh conflict. From Soviet past to postSoviet uncertainty. In E. Herzig \& M. Kurkchiyan (Eds.). The Armenians: Past and Present in the making of National Identity. (pp. 147-165). Abingdon, Oxon, Oxford, New York: RoutledgeCurzon.

de Waal, T. (2003) Black Garden. Armenia and Azerbaijan through Peace and War. New York and London: New York University Press.

\section{Journals \& Reports}

Abushov, K. (2009) Policing the near abroad: Russian foreign policy in the South Caucasus. Australian Journal of International Affairs. 63(2). pp. 187212.

Ambrosio, T. (2011) Unfreezing the NagornoKarabakh Conflict? Evaluating Peacemaking Efforts under the
Obama Administration. Ethnopolitics. 10(1). pp. 93-114.

Babbitt, E. F. (2006) Mediating Rights-Based Conflicts: Making Self-Determination Negotiable. International Negotiation. 11(1). pp. 185-208.

Baguirov, A. (2012). Nagorno-Karabakh: Competing Legal, Historic and Economic Claims in Political, Academic and Media Discourses. Journal of Muslim Minority Affairs. 32(2). 139-175.

Cheterian, V. (2012) Karabakh conflict after Kosovo: no way out? Nationalities Papers. 40(5). pp. 703-720.

Gahramanova, A. (2007) Peace strategies in "frozen" ethno-territorial conflicts: integrating reconciliation into conflict management. The case of NagornoKarabakh. Mannheim: Arbeitspapiere Mannheimer Zentrum für Europäische Sozialforschung. 103.

Gamaghelyan, P. (2010) Rethinking the Nagorno-Karabakh Conflict: Identity, Politics, Scholarship. International Negotiation. 15. pp. 33-56.

German, T. (2012). The Nagorno-Karabakh Conflict between Azerbaijan and Armenia: Security Issues in the Caucasus. Journal of Muslim Minority Affairs. 32(2).pp. 216-229.

Geybullayeva, A. (2012) Nagorno Karabakh 2.0: How New Media and Track Two Diplomacy Initiatives are Fostering Change. Journal of Muslim Minority Affairs. 32(2). pp. 176-185.

Ghaplanyan, I. (2010) Empowering and Engaging Civil Society in Conflict Resolution: The Case of NagornoKarabakh. International Negotiation. 15(1). pp. 81-106.

Harutunian, R. (2010) The NagornoKarabakh Conflict: Moving from Power Brokerage to Relationship Restructuring. International Negotiation. 15(1). pp. 57-80.

Hopmann, P. T. Z., Willam, I. (2010) Overcoming the Nagorno-Karabakh Stalemate. International Negotiation. 15(1). pp. 1-6. 
Huseynov, T. (2010) Mountainous Karabakh: New Paradigms for Peace and Development in the 21st century. International Negotiation. 15(1). pp. 7-31.

Kasim, K. (2012) American Policy toward the Nagorno-Karabakh Conflict and Implications for its Resolution. Journal of Muslim Minority Affairs. 32(2). pp. 230-244.

Milanova, N. (2003) The Territory-Identity Nexus in the Conflitct over Nagorno Karabakh: Implications for OSCE Peace Efforts. Journal on Ethnopolitics and Minority Issues in Europe. 4(2). pp. 1-25.

Moser, M. (2012) Der Konflikt um Bergkarabach. In P. M. Riener, Moritz; Roithner, Thomas (Ed.), "Vergessene Kriege" Konflikte abseits der öffentlichen Aufmerksamkeit. Analysen und Perspektiven einer jungen ForscherInnengeneration. SAFRAN Schlaininger Arbeitspapiere für Friedensforschung, Abrüstung und nachhaltige Entwicklung. (Vol. Paper o8. pp. 163-172). Wien/Stadtschlaining:

Österreichisches Studienzentrum für Frieden und Konfliktlösung (ÖSFK).

NKR, N.S.S.o. (2012) The Statistical Yearbook of Nagorno-Karabakh Republic, 20052011: National Statistical Service of NKR.

Özkan, B. (2008) Who gains from the "No War No Peace" Situation? A Critical Analysis of the Nagorno-Karabakh Conflict. Geopolitics. 13(3). pp. 572599.

Pokalova, E. (2015) Conflict Resolution in Frozen Conflicts: Timing in NagornoKarabakh. Journal of Balkan and Near Eastern Studies. 17(1). pp. 6885 .

Potier, T. (2012) Referendum to Determine Nagorno-Karabakh's Final Status: A Critical Appraisal. Journal of Muslim Minority Affairs. 32(2). pp. 269-276.

Riener, P.M. \& Roithner, T. (eds.) (2012) Vergessene Kriege" Konflikte abseits der öffentlichen Aufmerksamkeit.
Analysen und Perspektiven einer jungen ForscherInnengeneration. SAFRAN Schlaininger Arbeitspapiere für Friedensforschung, Abrüstung und nachhaltige Entwicklung. Wien/Stadtschlaining:

Österreichisches Studienzentrum für Frieden und Konfliktlösung (ÖSFK).

Tarnoff, C. (2004) The Former Soviet Union and U.S. Foreign Assistance in 1992: The Role of Congress. (Vol. 2013).

Uzer, U. (2012) Nagorno-Karabakh in Regional and World Politics: A Case Study for Nationalism, Realism and Ethnic Conflict. Journal of Muslim Minority Affairs. 32(2). pp. 245-252.

de Waal, T. (2010) Remaking the NagornoKarabakh Peace Process. Survival. 52(4). pp. 159-176.

\section{Online Articles}

Agayev, Z. (2013) Azeri-Russian Arms Trade \$4 Billion Amid Tension with Armenia[Online]. Bloomberg, August 14. Available from: http://www. bloomberg.com/news/2013-08-13/ azeri-russian-arms-trade-4-billionamid-tension-with-armenia.html [accessed 15 October 2014].

Chirila, V. (2013) How Civil Society is working to thaw "frozen conflicts" in Eurasia [online]. Open Society Foundations, January 21. Available from: http://www.opensocietyfoundations.o $\mathrm{rg}$ /voices/how-civil-society-workingthaw-frozen-conflicts-eurasia [accessed 13 October 2014].

IDMC - Internal Displacement Monitoring Centre (2014) Azerbaijan: After more than 20 years, IDPs still urgently need policies to support full integration[online]. Available from: http://www.internal-displacement. org/europe-the-caucasus-and-centralasia/azerbaijan/2014/azerbaijan-after -more-than-20-years-idps-still-urgent ly-need-policies-to-support-full-inte gration [accessed 22 October 2014].

Markedonov, S. (2014) Nagorno-Karabakh, 20 years later [online]. Russia Direct, May 12. Available from: 
http://www.russia-

direct.org/analysis/nagorno-karabakh -20-years-later [accessed 22 October 2014].

NKRUSA (2002) Nagorno Karabakh Peace Process. (Position Paper) [Online]. Washington: Office of the NagornoKarabakh Republic. Available from: http://www.nkrusa.org/nk_conflict/n kr_position.shtml [accessed 8 May 2013].

NKRUSA. (n.d.) US Response and Involvement [Online]. Washington: Office of the Nagorno-Karabakh Republic. Available from: http://www. nkrusa.org/nk_conflict/us_response. shtml [accessed 8 May 2013].

President, O. o. t. N. (n.d.). Ex-Presidents. Available from: http://www.presi dent.nkr.am/en/nkr/expresidents/ [accessed 28 May 2013].

Worldbank (2013) Defining Civil Society [Online]. Washington: The World Bank Group. Available from: http://web.worldbank.org/WBSITE/ EXTERNAL/TOPICS/CSO/o,,content MDK:20101499 menuPK:244752 pa gePK:220503 piPK:220476 theSiteP K:228717,0o.html [accessed 12 October 2014]. 
